\title{
FAKTOR PENENTU KUALITAS AUDIT MELALUI ANALISIS VARIABEL PROFESIONALISME, KOMPETENSI DAN INDEPENDENSI AUDITOR
}

\author{
I Made Purba Astakoni ${ }^{1}$, I Wayan Wardita ${ }^{2}$, Ni Made Satya Utami ${ }^{3}$, Ni Putu Nursiani ${ }^{4 *}$ \\ 1,2 Prodi Manajemen Sekolah Tinggi Ilmu Manajemen Handayani Denpasar \\ ${ }^{3}$ Prodi Manajemen Fakultas Ekonomi \& Bisnis Univ,Mahasaraswati Denpasar \\ ${ }^{4}$ Prodi Manajemen Fakultas Ekonomi \& Bisnis Undana Kupang-NTT \\ *e-mail: astakonimade@gmail.com
}

DiPublikasi: 01/01/2021

http://dx.doi.org/10.22225/kr.11.2.1154.190-196

\begin{abstract}
This study has several objectives: 1) to determine and analyze the effect of auditor professionalism on audit quality; 2) to determine and analyze the effect of auditor competence on audit quality; 3) to identify and analyze the effect of auditor independence on audit quality. This research was conducted in several public accounting firms in Denpasar City with the research subjects being all auditors. The sample in this study were all auditors in Denpasar City as many as 112 people. Data collection techniques used were interviews with questionnaires with closed multiple choice. In this study, data analysis used the Partial Least Square (PLS) approach. The results of the study found that the overall strength of the model by looking at the coefficient of determination, Q-Square Predictive Relevance and Goodness of Fit (GoF) were declared very good. The first hypothesis, which states that auditor professionalism has a significant positive effect on audit quality. In testing, it was found that the professionalism of the auditors had a negative effect with a p-value below the specified standard, it means that hypothesis 1 (H1) cannot be accepted. Second hypothesis. which states that auditor competence has a significant positive effect on audit quality. In testing, it was found that the auditor's competence had a positive effect with a p-value above the set standard, it means that hypothesis 2 (H2) can be accepted. The third hypothesis, which states that auditor independence has a significant positive effect on audit quality. In testing, it was found that the auditor's independence had a positive effect with a p-value above the set standard, it means that hypothesis 3 (H3) can be accepted.

Keywords: Auditor professionalism, auditor competence, audit independence and audit quality.

Abstrak

Penelitian ini memiliki beberapa tujuan ;1) untuk mengetahui dan menganalisis pengaruh profesionalisme auditor terhadap kualitas audit; 2) untuk mengetahui dan menganalisis pengaruh kompetensi auditor terhadap kualitas audit;3) untuk mengetahui dan menganalisis pengaruh independensi auditor terhadap kualitas audit. Penelitian ini dilakukan di beberapa Kantor Akuntan Publik (KAP) di Kota Denpasar dengan subyek penelitian adalah seluruh auditor. Sampel dalam penelitian ini adalah seluruh auditor yang ada di Kota Denpasar sebanyak 112 orang. Teknik pengumpulan data yang digunakan adalah wawancara dengan alat bantu kuesioner dengan pilihan ganda tertutup. Dalam penelitian ini analisis data menggunakan pendekatan Partial Least Square (PLS). Hasil penelitian menemukan bahwa kekuatan model secara keseluruhan dengan melihat koefisien determinasi, Q-Square Predictive Relevance dan Goodness of Fit $(\mathrm{GoF})$ dinyatakan sangat baik. Hipotesis pertama, yang menyatakan profesionalisme auditor berpengaruh signifikan positif terhadap kualitas audit. Dalam pengujian, diperoleh bahwa profesionalisme auditor berpengaruh negatif dengan dengan p-value dibawah standar yang ditetapkan, itu berarti hipotesis $1\left(\mathrm{H}_{1}\right)$ tidak dapat diterima. Hipotesis kedua. yang menyatakan kompetensi auditor berpengaruh signifikan positif terhadap kualitas audit. Dalam pengujian, diperoleh bahwa kompetensi auditor berpengaruh positif dengan p-value diatas standar yang ditetapkan, itu berarti hipotesis $2\left(\mathrm{H}_{2}\right)$ dapat diterima. Hipotesis ketiga, yang menyatakan independensi auditor berpengaruh signifikan positif terhadap kualitas audit. Dalam pengujian, diperoleh bahwa independensi auditor berpengaruh positif dengan p-value diatas standar yang ditetapkan, itu berarti hipotesis $3\left(\mathrm{H}_{3}\right)$ dapat diterima.
\end{abstract}

Kata Kunci : Profesionalisme auditor, Kompetensi auditor, Independensi auditor dan Kualitas audit.

\section{PENDAHULUAN}

Laporan keuangan merupakan hal yang penting bagi perusahaan, terutama bagi perusahaan go public. Oleh karena itu, diperlukan jasa penjaminan dari pihak independen untuk memberikan keyakinan bahwa laporan keuangan yang disajikan pihak manajemen perusahaan bebas dari salah saji material sehingga laporan keuangan 
dapat dipercaya dan dapat digunakan sebagai dasar dalam pengambilan keputusan (Hayati 2011).Laporan keuangan adalah hal penting yang menjadi acuan sarana komunikasi perusahaan dengan pihak luar seperti investor yang isinya memberikan informasi hasil kinerja manajemen dalam mengelola sumber-sumber daya perusahaan dan posisi keuangan pada periode tertentu. Laporan keuangan yang disusun oleh perusahaan digunakan pemegang saham, investor, kreditor, pemerintah dan pemegang kepentingan lainnya untuk membuat keputusan ekonomi sehingga informasi yang terkandung di dalamnya harus relevan, handal, dan bebas dari salah saji material. Perusahaan dalam mempertanggungjawabkan aktivitas bisnisnya dan menilai kinerja organisasi diharuskan untuk menyampaikan laporan keuangan yang disusun sesuai Standar Akuntansi Keuangan (SAK) dan memberikan hak kepada publik untuk mengetahui segala informasi yang berkaitan dengan perusahaan tersebut. Agar laporan keuangan tersebut relevan, handal, dan bebas dari salah saji yang material maka laporan keuangan tersebut harus diaudit oleh pihak ketiga yaitu auditor eksternal untuk memeriksa dan memberikan opini terhadap kewajaran laporan keuangan tersebut yang berguna untuk menghindari salah saji material pada laporan keuangan.

Menurut Undang-Undang nomor 5 tahun 2011, jasa akuntan publik merupakan jasa yang digunakan dalam pengambilan keputusan ekonomi dan berpengaruh secara luas dalam era globalisasi yang memiliki peran penting dalam mendukung perekonomian nasional yang sehat dan efisien serta meningkatkan transparansi dan mutu informasi dalam bidang keuangan. Akuntan Publik adalah seseorang yang telah memperoleh izin untuk memberikan jasa sebagaimana diatur dalam Undang-Undang nomor 5 tahun 2011. Dalam memberikan opini, auditor didasarkan pada pekerjaan audit yang telah dilakukannya dimana para pihak dari luar perusahaan lebih mengandalkan laporan keuangan yang telah diaudit untuk membuat keputusan-keputusan bisnis yang penting karena laporan keuangan yang telah diaudit memberikan penilaian yang objektif dan bebas dari adanya berbagai konflik kepentingan (conflict of interest)(Pektra dan Kurnia 2015). Dalam melaksanakan tugas auditnya seorang auditor harus berpedoman pada standar audit yang ditetapkan oleh Ikatan Akuntan Publik Indonesia (IAPI) yakni standar umum, standar pekerjaan lapangan dan standar pelaporan. Selain standar audit, seorang auditor juga harus mematuhi kode etik profesi yang mengatur tentang tanggung jawab profesi, kompetensi dan kehati-hatian professional, kerahasiaan, perilaku profesional serta standar teknis bagi seorang auditor dalam menjalankan profesinya. Kepercayaan yang besar dari pemakai laporan keuangan auditan dan jasa lainnya yang diberikan oleh akuntan publik inilah yang akhirnya mengharuskan akuntan publik memperhatikan kualitas audit yang dihasilkannya (Agusti dan Pertiwi 2013).

Ada banyak faktor yang dapat mempengaruhi kualitas audit seorang auditor. Dari beberapa kajian empirin terdahulu bisa dipaparkan bahwa kualitas audit dipengaruhi oleh variable kompetensi , independensi dan motivasi (Efendy 2010). Tjun, Marpaung, and Setiawan (2012), Giovani and Rosyada (2019) mengangkat variable kompetensi dan independensi auditor yang mempengaruhi kualitas auditor. Ningsih and Yaniartha (2013) mengangkat variable time budget pressure, kompetensi dan independensi auditor sebagai variable independen yang mempengaruhi kualitas audit. Peneliti lain dengan variable independent kompetensi , independensi dan profesionalisme auditor (Agusti and Pertiwi 2013). Deribe and Regasa (2014) dalam kajian empirisnya di Ethiopian Commercial Banks mengangkat variable independent competence, objectivity, performance yang mempengaruhi audit quality. Suyono (2012) dalam risetnya mengangkat variable perception, independence, experience, accountability sebagai factor penentu audit quality. Suseno (2013) mencoba menampilkan variabel independence, audit fees sebagai determinan audit quality. Peneliti yang lain mengangkat variable Audit Tenure, Audit Firm Size, Board Independence, Ownership Structure sebagai faktor penentu audit quality (Enofe et al. 2013). Jamaluddin and Syarifuddin (2014) menampilkan variabel independen ambiguitas peran, konflik peran, independensi yang mempengaruhi kualitas audit. Sari, Wardoyo, and Laily (2015) mengangkat variable independensi, skeptisme professional, perilaku disfungsional, etika profesi sebagai penentu kualitas audit.

Dari beberapa kajian empiris yang ada 
ternyata memberikan hasil yang berbeda dan bahkan kontradiktif. Kajian empiris Pinto, Rosid, and Baridwan (2020) mendapatkan profesionalisme auditor tidak berpengaruh terhadap kualitas audit. Hasil riset Efendy (2010), Tjun, Marpaung, and Setiawan (2012), Ningsih and Yaniartha (2013),Agusti and Pertiwi (2013), Anugerah and Akbar (2014), Giovani and Rosyada (2019), Pinto, Rosid, and Baridwan (2020) hasil penelitian menemukan kompetensi berpengaruh signifikan positif terhadap kualitas audit. Sementara hasil penelitian yang menunjukkan kompetensi tidak berpengaruh terhadap kualitas audit didapat oleh (Tarigan and Susanti 2013). Hasil penelitian Bolang, Sondakh, and Morasa (2013) yang menunjukkan kompetensi berpengaruh positif tidak signifikan terhadap kualitas audit.Penelitian yang dilakukan oleh Suseno (2013) ,Enofe et al. (2013), Enofe et al. (2013) Ningsih and Yaniartha (2013), Rahmina and Agoes (2014)Jamaluddin and Syarifuddin

\section{TINJAUAN PUSTAKA}

\section{Teori agensi}

Teori keagenan yang dikembangkan oleh Jensen \& Meckling, (1976) memberikan konsep hubungan keagenan sebagai kontrak, di mana satu atau lebih prinsipal meminta pihak lain sebagai agen untuk melakukan sejumlah pekerjaan atas nama prinsipal. Jadi dalam hal ini melibatkan pendelegasian beberapa kewenangan pengambilan keputusan kepada agen. Teori keagenan membantu para auditor sebagai pihak ketiga untuk memediasi konflik kepentingan yang muncul antara agen dan prinsipal. Teori keagenan digunakan untuk menjelaskan bahwa seorang auditor dengan kualitas audit yang tinggi akan didukung oleh sikap profesionalisme, kompetensi dan pengalaman kerja, akan memiliki kemampuan untuk mendeteksi kecurangan yang dilakukan oleh manajemen. Laporan keuangan yang diaudit oleh auditor diharapkan dapat dipercaya dan digunakan oleh berbagai pihak yang berkepentingan.

\section{Auditing}

Arens and Loebbecke $(2009 ; 17)$ mengemukakan definisi auditing sebagai berikut: "Auditing adalah pengumpulan serta pengevaluasian bukti-bukti atas informasi untuk menentukan dan melaporkan tingkat kesesuaian informasi tersebut dengan kriteria-kriteria yang telah ditetankan Auditino harus dilaksanakan oleh
(2014),Sari, Wardoyo, and Laily (2015) Giovani and Rosyada (2019), menyatakan bahwa independensi berpengaruh signifikan positif terhadap kualitas audit. Sementara kajian empiris Tjun, Marpaung, and Setiawan (2012), Efendy (2010) menemukan independensi auditor tidak berpengaruh terhadap kualitas audit.

Studi kali ini merupakan reflikasi dari riset sebelumnya dengan mengangkat kembali konstruk profesionalisme auditor, kompetensi dan independensi dalam mempengaruhi konstruk kualitas audit. Adapun subyek penelitian pada Kantor Akuntan Publik (KAP) di Kota Denpasar . Tujuan dari studi ini adalah ; 1) untuk mengetahui dan menganalisis pengaruh profesionalisme auditor terhadap kualitas audit,2) untuk mengetahui dan menganalisis pengaruh kompetensi auditor terhadap kualitas audit;3) untuk mengetahui dan menganalisis pengaruh independensi auditor terhadap kualitas audit

seseorang yang kompeten dan independen.Boynton, Raymon, and Water $(2003 ; 5) \quad$ memberikan definisi auditing sebagai:"suatu proses sistematis untuk memperoleh serta mengevaluasi bukti secara obyektif mengenai asersi-asersi kegiatan dan peristiwa ekonomi, dengan tujuan menetapkan derajat kesesuaian antara asersi-asersi tersebut dengan kriteria yang telah ditetapkan sebelumnya serta penyampaian hasil-hasilnya kepada pihak-pihak yang berkepentingan. Menurut Mulyadi $(2002 ; 11)$ ditinjau dari sudut profesi akuntan publik, auditing adalah pemeriksaan secara objektif atas laporan keuangan suatu perusahaan atau organisasi lain dengan tujuan untuk menentukan apakah laporan keuangan tersebut menyajikan secara wajar, dalam semua hal yang material, posisi keuangan dan hasil usaha perusahaan atau organisasi tersebut. Proses audit merupakan suatu audit laporan yang menyatakan pendapat dalam laporan keuangan telah menyajikan secara wajar secara material sesuai dengan prinsip-prinsip akuntansi yang berlaku umum (SAK).

\section{Kualitas Audit}

Turley and Willekens (2008) menyatakan bahwa kualitas audit biasanya terkait dengan kemampuan auditor dalam mengidentifikasi salah saji material dalam laporan keuangan dan 
kesediaannya untuk menerbitkan laporan audit yang sesuai dan tidak bias berdasarkan hasil audit. Lebih lanjut Suseno (2013) sesuai Standar Internasional ISO 8402-1986 (1989) menyatakan bahwa kualitas audit adalah pemeriksaan yang sistematis dan independen untuk menentukan apakah kegiatan kualitas dan hasil terkait perusahaan sesuai dengan pengaturan yang direncanakan dan apakah pengaturan ini adalah diimplementasikan secara efektif dan cocok untuk mencapai tujuan. Sehubungan dengan layanan, Boynton et al. (2006) berpendapat bahwa setiap profesi secara konsisten terkait dengan kualitas layanan yang diberikannya, termasuk auditor di mana kualitas layanannya sangat penting untuk memastikan bahwa profesi ini bertanggung jawab kepada klien, orang-orang, dan peraturan. Kualitas audit mengacu pada standar dengan kriteria atau ukuran kualitas pelaksanaan dan juga terkait dengan tujuan yang ingin dicapai dengan menerapkan prosedur terkait. Singkatnya, dapat dinyatakan bahwa kualitas audit merupakan kemampuan atau keahlian auditor untuk mengidentifikasi dan melaporkan salah saji material yang signifikan dalam laporan keuangan klien.

\section{Profesionalisme Auditor}

Profesionalisme terkait dengan perilaku, tujuan, karakteristik, dan fitur orang profesional. Di antara fitur utama profesi akuntansi adalah kompetensi, ketidakberpihakan dan kepercayaan. Tindakan dan perilaku anggota profesi akuntansi didasarkan pada persyaratan dan peraturan perilaku profesional yang dikembangkan oleh asosiasi akuntansi profesional (Heyrani, Banimahd, and Roudposhti 2016).Profesionalisme auditor merupakan merupakan sikap auditor yang melaksanakan audit berpedoman pada standar yang berlaku. Profesionalisme auditor dapat ditunjukkan dengan sikap kehati- hatian dan cermat dalam pelaksanaan audit meliputi ketelitian dalam memeriksa kelengkapan kertas kerja, mengumpulkan bahan bukti audit yang memadai dan menyusun laporan audit yang lengkap (Badjuri 2013) .Auditor yang memiliki sikap profesionalisme yang baik dan tinggi akan menyajikan hasil pemeriksaan secara lengkap, memadai dan sesuai dengan standar yang berlaku (Suharti, Anugerah, and Rasuli 2017).

\section{Kompetensi Auditor}

Seorang yang berkompeten adalah orang yang dengan keterampilannya mengerjakan pekerjaan dengan mudah, cepat, intuitif dan sangat jarang atau tidak pernah membuat kesalahan (Agusti and Pertiwi 2013). Kompetensi sebagai suatu keahlian yang cukup secara eksplisit dapat digunakan untuk melakukan audit secara obyektif (Giovani and Rosyada 2019).Kompetensi auditor adalah auditor yang dengan pengetahuan dan pengalamannya yang cukup dan eksplisit dapat melakukan audit secara objektif, cermat dan seksama. Auditor yang berpendidikan tinggi akan mempunyai banyak pengetahuan mengenai bidang yang digelutinya, sehingga dapat mengetahui berbagai masalah secara lebih mendalam. Selain itu, dengan ilmu pengetahuan yang cukup luas, auditor akan lebih mudah dalam mengikuti perkembangan yang semakin kompleks.Jadi dengan begitu auditor akan dapat menghasilkan audit yang berkualitas tinggi.

\section{Independensi Auditor}

Menurut Halim (2008;46), independensi merupakan suatu cerminan sikap dari seorang auditor untuk tidak memilih pihak siapapun dalam melakukan audit. Independensi adalah sikap mental seorang auditor dimana ia dituntut untuk bersikap jujur dan tidak memihak sepanjang pelaksaan audit dan dalam memposisikan dirinya dengan auditeenya.Independensi berarti objektif dan tidak memihak saat melakukan layanan profesional. Independensi auditor dari perusahaan berarti bahwa audit adalah salah satu persyaratan dasar untuk menjaga kepercayaan publik terhadap keandalan laporan audit (Suseno 2013). Kemandirian menambah kredibilitas pada laporan audit di mana investor, kreditor, karyawan, pemerintah, dan pemangku kepentingan lainnya bergantung pada pengambilan keputusan tentang suatu perusahaan. Arens, Elder, and Bessley (2012) mengemukakan bahwa semua orang yang terlibat harus menjaga independensi dilapangan dan independensi dalam penampilan untuk melakukan tanggung jawab profesional dengan integritas dan menjaga obyektivitas dalam melakukan tanggung jawab profesional mereka. Integritas berarti bahwa seseorang bertindak berdasarkan hati nurani terlepas dalam situasi apapun, serta prinsip selalu memiliki objektivitas, tidak memihak dan bebas dari konflik kepentingan (Messier et al. 2008).

Efek positif dari profesionalisme auditor pada kualitas audit 
Sikap profesionalisme akan mengambil keputusan berdasarkan pertimbangan yang dimilikinya yaitu berdasarkan pengabdian pada profesi, kewajiban sosial, kemandirian dan yang terakhir hubungan dengan sesama profesi (Agusti and Pertiwi 2013). Auditor yang mampu melaksanakan hal-hal tersebut akan mampu memenuhi unsur profesionalisme auditor. Suharti, Anugerah, and Rasuli (2017) menyimpulkan bahwa akuntan dengan komitmen profesional yang kuat, perilakunya lebih mengarah pada aturan dibanding akuntan publik dengan komitmen profesional yang rendah. Artinya, sikap professional dari seorang auditor akan berdampak pada hasil audit yang baik. Jadi dengan demikian sikap professional dari seorang auditor diduga dapat mempengaruhi kualitas hasil audit. Badjuri (2013).Agusti and Pertiwi (2013), Suharti ( 2017 ), Iryani (2017), membuktikan bahwa profesionalisme berpengaruh signifikan positif terhadap kualitas hasil audit.. Walaupun K.P.Kambuaya (2018) dalam risetnya menemukan hal yang sebaliknya, bahwa profesionalime tidak berpengaruh terhadap kualitas hasil audit. Hal ini berarti semakin tinggi profesionalisme seorang auditor, maka akan menghasilkan kualitas audit yang semakin baik Berdasarkan paparan hasil riset sebelumnya maka hipotesis pertama yang diusulkan ( $\mathrm{H} 1)$ : profesionalisme auditor berpengaruh signifikan positif pada kualitas audit.

\section{Efek positif dari kompetensi auditor pada kualitas audit}

Auditor membutuhkan sebuah kompetensi. Kompetensi diperoleh melalui pendidikan dan pengalaman (Prihartini, Sulindawati, and Darmawan 2015). Para anggota seyogyanya tidak menggambarkan dirinya memiliki keandalan atau pengalaman yang tidak mereka miliki (Mulyadi 2002;58) Beberapa penelitian mengenai kompetensi sudah pernah dilakukan sebelumnya. Efendy (2010), Tjun, Marpaung, and Setiawan (2012), Ningsih and Yaniartha (2013),Agusti and Pertiwi (2013), Anugerah and Akbar (2014), Giovani and Rosyada (2019), hasil penelitiannya menunjukkan kompetensi berpengaruh signifikan positif terhadap kualitas audit. Sementara hasil penelitian yang menunjukkan kompetensi tidak berpengaruh terhadap kualitas audit didapat oleh (Tarigan and Susanti 2013). Hasil penelitian Bolang, Sondakh, and Morasa (2013),(Iryani 2017) yang menunjukkan kompetensi berpengaruh positif tidak signifikan terhadap kualitas audit. Berdasarkan paparan hasil riset sebelumnya maka hipotesis kedua yang diusulkan ( $\mathrm{H} 2$ ): kompetensi auditor berpengaruh signifikan positif pada kualitas audit.

Efek positif dari independensi auditor pada kualitas audit

Mulyadi (2002;9) mendefinisikan independensi sebagai keadaan bebas dari pengaruh, tidak dikendalikan oleh pihak lain, tidak tergantung pada orang lain dan akuntan publik yang independen haruslah akuntan publik yang tidak terpengaruh dan tidak dipengaruhi oleh berbagai kekuatan yang berasal dari luar diri akuntan dalam mempertimbangkan fakta yang dijumpainya dalam pemeriksaan. Penelitian mengenai independensi sebelumnya pernah dilakukan oleh Suseno (2013), Enofe et al. (2013), Agusti and Pertiwi (2013), Enofe et al. (2013), Ningsih and Yaniartha (2013), Rahmina and Agoes (2014), Jamaluddin and Syarifuddin (2014),Sari, Wardoyo, and Laily (2015), Giovani and Rosyada (2019),yang menyatakan bahwa independensi berpengaruh signifikan positif terhadap kualitas audit. Hal ini berarti semakin tinggi independensi seorang auditor, maka akan menghasilkan kualitas audit yang semakin baik. Sementara kajian empiris Tjun, Marpaung, and Setiawan (2012), Efendy (2010) S u har ti 2017 Iryani 2017 (yg diprint menemukan independensi auditor tidak berpengaruh terhadap kualitas audit. Berdasarkan paparan hasil riset sebelumnya maka hipotesis ketiga yang diusulkan ( $\mathrm{H} 3$ ); independensi auditor berpengaruh signifikan positif pada kulalitas audit

Mengacu pada hipotesis yang diusulkan, maka model penelitian ini dapat digambarkan sebagai berikut (Gambar 1) 


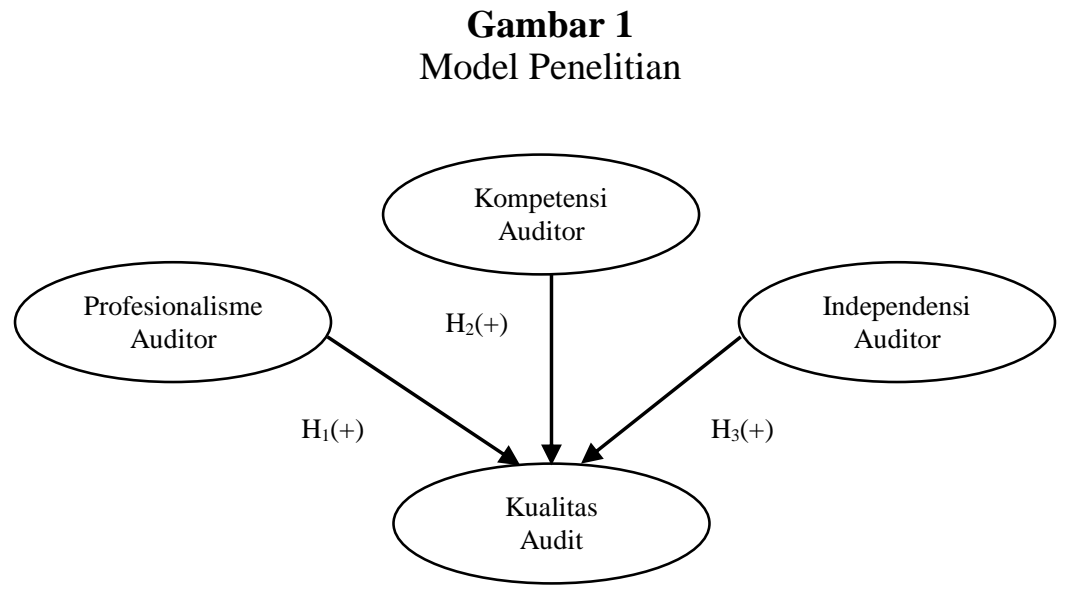

III.

\section{METODE PENELITIAN}

\section{Desain Penelitian}

Desain penelitian yang digunakan dalam studi ini adalah kausal, yakni model riset yang menjelaskan hubungan kausal antar variabel penelitian. Pola hubungan antar variabel laten dalam studi ini sebagai akibat dari adanya keterkaitan variabel eksogen terhadap variabel endogen,maka sifat dari pada variabel/konstruk dalam studi ini bersifat un_observe (laten variabel) maka digunakan pendekatan dengan pengukuran melalui indikator.

\section{Tempat \& Obyek Penelitian}

Penelitian ini dilakukan di beberapa Kantor Akuntan Publik (KAP) di Kota Denpasar dengan subyek penelitian adalah seluruh auditor dari 12 KAP. Adapun obyek atau variabel dari penelitian ini adalah kualitas audit, profesiolalisme auditor, kompetensi auditor dan independensi auditor.

\section{Populasi,Sampel dan Pengumpulan Data}

Populasi adalah gabungan dari seluruh elemen yang berbentuk peristiwa, hal, atau orang yang memiliki karakteristik serupa yang menjadi pusat perhatian peneliti, oleh karenanya dipandang sebagai semesta penelitian (Ferdinand 2014). Populasi dalam penelitian ini adalah seluruh auditor tahun 2019 yang ada di Kota Denpasar yang berjumlah 112 orang (dengan rincian KAP Drs Sri Marmo Gjokarsono \& Rekan dengan auditor sebanyak 25 orang; KAP K Gunarsa dengan auditor 19 orang; KAP Johan Malonda Mustika \& Rekan (Cab) sebanyak 18 orang; KAP Drs. Ketut Budiartha, M.Si sebanyak 10 orang; KAP Tjahjo,Machdjud Modoporo \& Rekan (Cab) sebanyak 9 orang; KAP I Wayan Ramanta sebanyak 8 orang; KAP Drs Ketut Muliartha R.M. \& Rekan sebanyak 8 orang; KAP Budhananda Munidewi sebanyak 6 orang; KAP Arimbawa sebanyak 3 orang ;serta KAP Artayasa;KAP Arnayasa -Darmayasa;KAP Rama Wendra masing masing 2 orang). Penentuan sampel dilakukan dengan cara melihat populasi secara keseluruhan sehingga sampel berjumlah 112 orang. Teknik pengumpulan data yang digunakan dalam penelitian ini adalah wawncara dengan alat bantu kuesioner dengan pilihan ganda tertutup. Sedangkan skala pengukuran yang digunakan adalah skala likert dengan interval jawaban: skor 5,jawaban sangat setuju (SS); skor 4, jawaban setuju (S) ; skor 3,jawaban netral ; skor 2,jawaban tidak setuju (TS) ; skor 1,jawaban sangat tidak setuju (STS).

\section{Definisi Operasional dan Indikator Variabel}

Kualitas Audit (Y)

Kualitas audit merupakan kemampuan atau keahlian auditor untuk mengidentifikasi dan melaporkan salah saji material yang signifikan dalam laporan keuangan klien. Kualitas audit dalam studi ini diukur dengan 8 indikator (Efendy 2010) yaitu keakuratan audit $\left(Y_{1.1}\right)$, tidak ada rekayasa) ( $\left.\mathrm{Y}_{1.2}\right)$, tanpa penyimpangan $\left(\mathrm{Y}_{1.3}\right)$, rekomendasi untuk perbaikan $\left(\mathrm{Y}_{1.4}\right)$, laporan dapat dipahami auditee $) \quad\left(\mathrm{Y}_{1.5}\right)$, menurunkan penyimpangan $\left(\mathrm{Y}_{1.6}\right)$,memberi kesempatan umpan balik) $\left(\mathrm{Y}_{1.7}\right)$, memantau tidak lanjut pemeriksaan) $\left(\mathrm{Y}_{1.8}\right)$.

Profesionalisme auditor (X1) 
Profesionalisme auditor didefinisikan kemampuan dan sikap professional dari auditor terutama dalam hal kinerja serta kualitas audit (Virgiawan and Oleona 2020).Ketegasan profesionalisme auditor yang tinggi dihargai karena membutuhkan kepercayaan public terkait dengan kualitas layanan yang diberikan oleh profesi auditor.Profesionalisme auditor dalam studi ini diukur dengan 5 indikator (Putri and Mardijuwono 2020) yaitu persepsi auditor atas dedikasinya pada profesi $\left(\mathrm{X}_{1.1}\right)$, persepsi auditor atas tanggung jawab social $\left(\mathrm{X}_{1.2}\right)$, persepsi auditor tentang kemandirian $\left(\mathrm{X}_{1.3}\right)$, persepsi auditor tentang kesetiaan profesional $\left(\mathrm{X}_{1.4}\right)$, persepsi auditor atas hubunagan antara asosiasi pada profesi yang sama $\left(\mathrm{X}_{1.5}\right)$.

Kompetensi auditor (X2)

Kompetensi auditor adalah auditor yang dengan pengetahuan dan pengalamannya yang cukup dan eksplisit dapat melakukan audit secara objektif, cermat dan seksama.Kompetensi dalam studi ini diukur dengan 6 indikator (Efendy 2010) yaitu; pendidikan formal) $\left(\mathrm{X}_{2.1}\right)$, sesuai standar akuntansi $\left(\mathrm{X}_{2.2}\right)$, memiliki wawasan tentang organisasi) $\left(\mathrm{X}_{2.3}\right)$, keahlian $\left(\mathrm{X}_{2.4}\right)$, pelatihan $)\left(\mathrm{X}_{2.5}\right)$, punya inisiatif) $\left(\mathrm{X}_{2.6}\right)$

Independensi auditor (X3)

Independensi seorang auditor dalam arti bertindak berdasarkan hati nurani terlepas dalam situasi apapun, serta prinsip selalu memiliki objektivitas, tidak memihak dan bebas dari konflik kepentingan. Independensi dalam studi ini diukur dengan 5 indikator (Mulyadi 2002;26) yaitu; sikap mental bebas dari pengaruh pihak lain $\mathrm{X}_{3.1}$ ), tidak dikendalikan pihak lain $\left(\mathrm{X}_{3.2}\right)$, tidak tergantung orang lain $\left(\mathrm{X}_{3.3}\right)$, kejujuran yang melekat dalam diri $\left(\mathrm{X}_{3.4}\right)$, memberikan pertimbangan yang obyektif $\left(\mathrm{X}_{3.5}\right)$

\section{Gambar 2}

Konstruk laten dan indikator

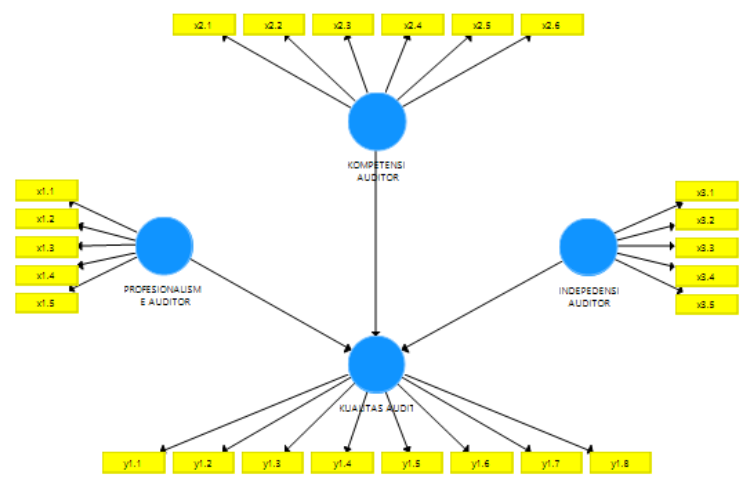

Teknik Analisis Data

Analisis Statistik Deskriptif

Analisis deskriptif dipergunakan untuk menggambarkan karakteristik responden dan karakteristik jawaban responden terhadap indikator-indikator yang diangkat dari konstruk penelitian.

Analisis Statistik Inferensial

Dalam penelitian ini analisis data menggunakan pendekatan Partial Least Square (PLS). Dalam PLS path modeling terdapat dua model yaitu outler model dan inner model, dimana kedua kriteria ini digunakan dalam penelitian ini. Evaluasi model pengukuran (measurement model/outer model), untuk mengukur validitas dan reliabilitas indikator-indikator tersebut adalah convergent validity, discriminant validity, dan composite reliabilitya (Sabil 2019) .Evaluasi model struktural (Structural Model/Inner Model) adalah pengukuran untuk mengevaluasi tingkat ketepatan model dalam penelitian secara keseluruhan, yang dibentuk melalui beberapa variabel beserta dengan indikator-indikatornya. Dalam evaluasi model struktural ada beberapa pendekatan diantaranya : a) $R$-Square atau koefisien determinasi, b) Q-Square Predictive Relevance $\left(Q^{2}\right)$ didapatkan melalui proses Blinfolding $P L S$, dengan kriteria $\mathrm{Q}^{2}>0$ ), dan c) Goodness of Fit (GoF) (Sabil 2019) dengan ketentuan $\mathrm{GoF}=0,10$ (Small) $\mathrm{GoF}=0,25$ (Medium) $\mathrm{GoF}=0,36$ ( Large). 


\section{HASIL DAN PEMBAHASAN}

\section{Hasil Penelitian}

\section{Deskripsi Karateristik Responden}

Karateristik responden merupakan gambaran dari keberadaan responden yang terlibat dalam penelitian yaitu berdasarkan jenis kelamin , masa kerja, pendidikan terakhir. Dari seluruh populasi karyawan perusahaan yang berjumlah 112 orang yang diteliti, hanya dapat mengisi dan mengembalikan kuesioner yang diberikan sebanyak 101 orang. Atas dasar hasil tabulasi silang (cross-tabulation) maka secara lebih detail distribusinya bisa dilihat lewat Tabel 1 berikut:

Tabel 1

Deskripsi Karakteristik Responden Penelitian

\begin{tabular}{|c|c|c|c|c|c|}
\hline \multirow{2}{*}{$\begin{array}{c}\text { Jenis } \\
\text { Kelamin }\end{array}$} & \multirow{2}{*}{$\begin{array}{c}\text { Tingkat } \\
\text { Pendidikan }\end{array}$} & \multicolumn{3}{|c|}{ Lama Kerja Responden (tahun) } & \multirow[t]{2}{*}{ Total } \\
\hline & & $<3$ & $3-5$ & $>5$ & \\
\hline \multirow[t]{5}{*}{ Laki } & Diploma & 12 & 2 & 2 & 16 \\
\hline & Sarjana & 9 & 2 & 10 & 21 \\
\hline & Pascasarjana & 5 & 5 & 0 & 10 \\
\hline & Sub total & 26 & 9 & 12 & 47 \\
\hline & Dinlom & 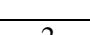 & 0 & 3 & $\frac{(46,53)}{5}$ \\
\hline \multirow{3}{*}{ Perempuan } & Sarjana & 9 & 30 & 2 & 41 \\
\hline & Pascasarjana & 8 & 0 & 0 & 8 \\
\hline & Sub total & 19 & 30 & 5 & $\begin{array}{c}54 \\
(53,47)\end{array}$ \\
\hline \multirow[t]{4}{*}{ Total } & $<30$ & 14 & 2 & 6 & 21 \\
\hline & $40-49$ & 18 & 32 & 12 & 62 \\
\hline & $>=50$ & 13 & 5 & 0 & 10 \\
\hline & Total & $\begin{array}{c}45 \\
(44,60)\end{array}$ & $\begin{array}{c}39 \\
(38,60)\end{array}$ & $\begin{array}{c}17 \\
(16,80)\end{array}$ & $\begin{array}{c}101 \\
(100,00)\end{array}$ \\
\hline
\end{tabular}

Secara keseluruhan responden penelitian berjumlah 101 orang auditor, dengan jenis kelamin laki-laki sebanyak 47 orang $(46,53 \%)$ dan perempuan sebanyak 54 orang $(53,47 \%)$. Bila diamati dari sisi pendidikan, responden laki-laki sebagian besar berpendidikan sarjana dengan masa kerja diatas 5 tahun. Sedangkan responden perempuan sebagian besar berpendidikan sarjana dengan masa kerja diatas 3-5 tahun. Secara keseluruhan sebagian besar masa kerja responden berada pada interval <3tahun sebanyak 44,60\%, masa kerja 3-5 tahun sebanyak 38,60\% dan sisanya dengan masa kerja $>$ tahun sebanyak $17 \%$

\section{Statistik Inferensial}

\section{Evaluasi Outler Model}

Didalam mengevaluasi indikator-indikator kontruk laten dari ke-4 konstruk yang diangkat, dilakukan melalui satu kali iteraksi sehingga akhirnya didapat hasil yang memenuhi ketentuan yang ada (Gambar 3)

\section{Gambar 3}

Path Diagram Hasil Evaluasi Outler Model

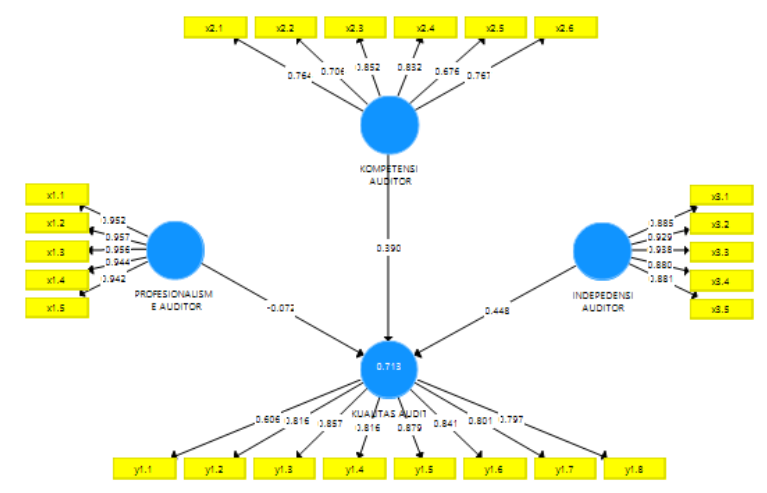


Convergent Validity

Indikator individu dianggap valid jika memiliki

outler loading diatas $(>0,50)$ dan nilai AVE $>0,50$

Tabel 2

Outer Loading Hasil Estimasi Model

\begin{tabular}{|c|c|c|c|c|}
\hline Indikator & $\begin{array}{c}\text { Profesionalisme } \\
\text { Auditor }\end{array}$ & $\begin{array}{c}\text { Kompetensi } \\
\text { Auditor }\end{array}$ & $\begin{array}{c}\text { Independensi } \\
\text { Auditor }\end{array}$ & $\begin{array}{c}\text { Kualitas } \\
\text { Audit }\end{array}$ \\
\hline X1.1 & 0,952 & & & \\
X1.2 & 0,957 & & & \\
X1.3 & 0,956 & & & \\
X1.4 & 0,944 & 0,764 & & \\
X1.5 & 0,942 & 0,706 & \\
X2.1 & & 0,852 & & \\
X2.2 & & 0,832 & & \\
X2.3 & & 0,676 & & \\
X2.4 & & & 0,885 & \\
X2.5 & & & 0,929 & \\
X2.6 & & & 0,938 & \\
X3.1 & & & 0,880 & \\
X3.2 & & & & 0,606 \\
X3.3 & & & & 0,857 \\
X3.4 & & & & 0,816 \\
X3.5 & & & & 0,841 \\
Y1.1 & & & 0,707 \\
Y1.2 & & & & \\
Y1.3 & & & & \\
Y1.4 & & & & \\
Y1.5 & & & & \\
Y1.6 & & & & \\
Y1.7 & & & & \\
Y1.8 & & & & \\
\hline
\end{tabular}

Tabel 3

Nilai Average Variance Extracted (AVE) Konstruk Laten

\begin{tabular}{|c|c|}
\hline Konstruk & $A V E$ \\
\hline Profesionalisme Auditor & 0,903 \\
Kompetensi auditor & 0,591 \\
Independensi Auditor & 0,815 \\
Kualitas Audit & 0,649 \\
\hline
\end{tabular}

Hasil analisis menunjukkan niai outler loading dan Nilai Average Variance Extracted (AVE) (Tabel 2 dan Tabel 3) dari seluruh indikator yang merefleksikan masing-masing konstruk memiliki nilai outer loading> 0,50 dan nilai AVE $>0,50$ maka seluruh indikator dinyatakan valid sebagai pengukur konstruk.

\section{Discriminant Validity}

Pengukuran validitas indikator-indikator yang membentuk variabel laten, dapat pula dilakukan melalui discriminant validity. Output discriminant validity ditunjukkan lewat HTMT (Heterotrait-Monotrait Ratio <0,90) sehingga dinyatakan valid. Output discriminant validity ditunjukkan lewat data Tabel 4 berikut

Tabel 4

Uji Discriminant Validity (HTMT)

\begin{tabular}{|c|c|c|c|c|}
\hline Konstruk & $\begin{array}{c}\text { Profesionalisme } \\
\text { Auditor }\end{array}$ & $\begin{array}{c}\text { Kompetensi } \\
\text { Auditor }\end{array}$ & $\begin{array}{c}\text { Independensi } \\
\text { Auditor }\end{array}$ & $\begin{array}{c}\text { Kualitas } \\
\text { Audit }\end{array}$ \\
\cline { 2 - 6 } & - & 0,597 & 0,831 & 0,673 \\
Profesionalisme Auditor & - & - & 0,869 & - \\
Kompetensi auditor & - & - & - & - \\
Independensi Auditor & - & 0,872 & 0,860 & - \\
\hline Kualitas Audit
\end{tabular}




\section{Composite Reliability}

Suatu pengukuran dapat dikatakan reliabel, apabila composite reliability dan cronbach alpha memiliki nilai lebih besar dari 0,70. Composite reliability adalah merupakan suatu pengukuran reliabilitas antar blok indikator dalam model penelitian.

\section{Tabel 5.}

Uji Composite Reliability

\begin{tabular}{|c|c|c|}
\hline Konstruk & Composite Reliability & Cronbach Alpha \\
\hline Profesionalisme Auditor & 0,979 & 0,973 \\
Kompetensi auditor & 0,896 & 0,860 \\
Independensi Auditor & 0,957 & 0,943 \\
Kualitas Audit & 0,936 & 0,921 \\
\hline
\end{tabular}

Tabel 6 menunjukkan bahwa nilai composite reliability seluruh konstruk telah menunjukkan nilai > 0.70 sehingga memenuhi syarat reliable berdasarkan criteria composite reliability.

\section{Evaluasi Inner Model}

Uji Inner Model dipergunakan untuk mengevaluasi model secara keseluruhan dengan alat analisis dilihat dari sisi R-Square $\left(\mathrm{R}^{2}\right), Q$ Square Predictive Relevance $\left(\mathrm{Q}^{2}\right)$ dan Goodness of Fit (GoF)

Tabel 6

Uji Model Keseluruhan

\begin{tabular}{|c|c|c|c|}
\hline Konstruk & R.Square & $\mathrm{Q}^{2}$ & GoF \\
\hline Kualitas Audit & 0,713 & 0,453 & 0,574 \\
\hline
\end{tabular}

Berdasarkan Tabel 6, untuk mengevaluasi model secara keseluruhan dengan alat analisis dilihat dari sisi R-Square $\left(\mathrm{R}^{2}\right)$ sebesar $71,30 \%$ , Q-Square Predictive Relevance $\left(\mathrm{Q}^{2}\right)$ sebesar 0,453 dan Goodness of Fit (GoF) maka model sebesar 0,574 (large), sehingga secara keseluruhan model dinyatakan sangat baik.

Pengujian hubungan antar konstruk laten seperti yang telah dihipotesiskan dalam penelitian dilakukan melalui proses resampling dengan metode bootstrapping, didapat hasil sesuai Gambar 4 berikut:

\section{Gambar 4}

Output bootstrapping path coefficient sample

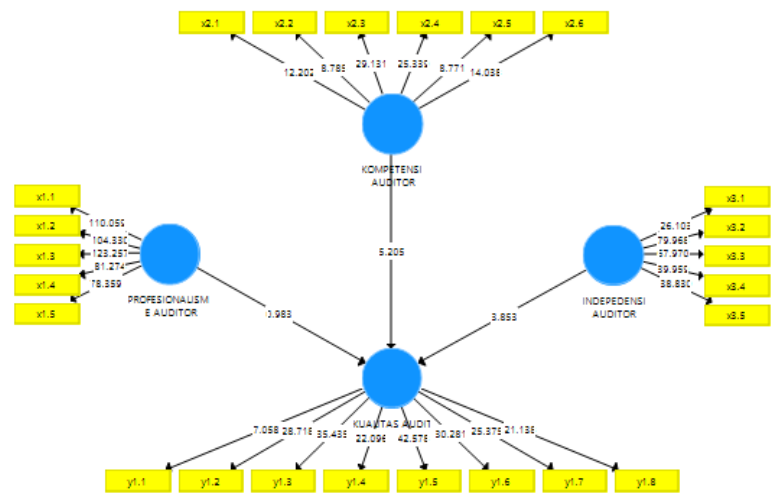

Hasil dari Inner Weight pada Gambar 3 menunjukkan bahwa kualitas audit dipengaruhi oleh profesionalisme auditor. kompetensi auditor dan independensi auditor, secara keseluruhan akan djelaskan pada pengujian hipotesis lewat paparan berikut.Tabel 7 memberikan output estimasi untuk pengujian model struktural dimana hasil yang diharapkan adalah Ho ditolak atau nilai sig < 
0,05 (atau nilai t statistic > 1,96 untuk uji dengan level of signifikan 0,05 ).

Tabel 7

Path Coefficient dan Hasil Uji Hipotesis

\begin{tabular}{|c|c|c|c|c|c|c|}
\hline Hubungan antar konstruk & $\begin{array}{c}\text { Original } \\
\text { Sample } \\
\text { (O) }\end{array}$ & $\begin{array}{l}\text { Sample Mean } \\
\text { (M) }\end{array}$ & $\begin{array}{l}\text { Standard } \\
\text { Deviation } \\
\text { (STDEV) }\end{array}$ & $\begin{array}{l}\text { T Statistics } \\
\text { (O/STERR) }\end{array}$ & $\begin{array}{c}\text { P- } \\
\text { Value }\end{array}$ & $\begin{array}{c}\text { Keterang } \\
\text { an }\end{array}$ \\
\hline $\begin{array}{l}\text { Profesionalisme Auditor } \rightarrow \text { Kualitas } \\
\text { Audit } \\
\text { Kompetensi Auditor } \rightarrow \text { Kualitas Audit } \\
\text { Independensi Auditor } \rightarrow \text { Kualitas Audit }\end{array}$ & $\begin{array}{c}-0,072 \\
0,390 \\
0,448\end{array}$ & $\begin{array}{r}-0,075 \\
0,392 \\
0,445\end{array}$ & $\begin{array}{l}0,073 \\
0,075 \\
0,116\end{array}$ & $\begin{array}{l}0,983 \\
5,206 \\
3,853\end{array}$ & $\begin{array}{l}0,326 \\
0,000 \\
0,000\end{array}$ & $\begin{array}{l}\text { Tidak Signifikan } \\
\text { Sisnifikan } \\
\text { Signifikan }\end{array}$ \\
\hline
\end{tabular}

\section{Pembahasan}

Efek positif profesionalisme auditor terhadap kualitas audit

Hipotesis 1, yang menyatakan profesionalisme auditor berpengaruh positif signifikan terhadap kualitas audit. Dalam pengujian , diperoleh bahwa profesionalisme auditor berpengaruh negatif dengan koefisien $-0,072$ (negatif) serta p-value 0,326 (atau t-statistik $0,983<1,96)$, berarti hipotesis $1\left(\mathrm{H}_{1}\right)$ tidak dapat diterima, sehingga hal ini tidak sesuai dengan pernyataan bahwa semakin tinggi profesionalisme auditor maka akan semakin baik pula kualitas audit yang dihasilkan. Hasil penelitian ini tidak mendukung kajian empiris yang didapat oleh Badjuri (2013).Agusti and Pertiwi (2013), Suharti (2017), Iryani (2017), dimana hasil risetnya menyatakan bahwa profesionalisme berpengaruh signifikan positif terhadap kualitas audit. Walaupun ada temuan lain yang sejalan dengan temuan saat ini bahwa profesionalisme auditor tidak berpengaruh terhadap kualitas audit (K.P.Kambuaya,2018),(Pinto, Rosid, and Baridwan 2020)

Efek positif kompetensi auditor terhadap kualitas audit

Hipotesis 2, yang menyatakan kompetensi auditor berpengaruh signifikan positif terhadap kualitas audit. Dalam pengujian, diperoleh bahwa kompetensi auditor berpengaruh signifikan positif dengan koefisien 0,390 (positif) serta p-value 0,000 (atau t-statistik 5,205>1,96), berarti hipotesis $2\left(\mathrm{H}_{2}\right)$ dapat diterima, sehingga hal ini sesuai dengan pernyataan bahwa semakin tinggi kompetensi auditor maka akan semakin baik pula kualitas audit yang dihasilkan. Penelitian ini sejalan dengan kajian empiris Efendy (2010), Tjun, Marpaung, and Setiawan (2012), Ningsih and Yaniartha (2013)(Agusti and Pertiwi 2013),(Deribe and Regasa 2014) (Anugerah and Akbar 2014), Giovani and Rosyada (2019), yang menemukan kompetensi auditor berpengaruh signifikan positif terhadap kualitas audit. Sementara hasil penelitian ini tidak sejalan dengan temuan Tarigan and Susanti (2013) yang menunjukkan kompetensi tidak berpengaruh terhadap kualitas audit didapat. Hasil penelitian ini juga tidak mendukung temuan Bolang, Sondakh, and Morasa (2013) yang menunjukkan kompetensi berpengaruh positif tidak signifikan terhadap kualitas audit.

Efek positif independensi auditor terhadap kulaitas audit

Hipotesis 3, yang menyatakan independensi auditor berpengaruh positif signifikan terhadap kualitas audit. Dalam pengujian diperoleh bahwa independensi auditor berpengaruh positif dengan koefisien 0,448 (positif) serta p-value 0,000 (atau tstatistik 3,853>1,96),berarti hipotesis $3\left(\mathrm{H}_{3}\right)$, dapat diterima, sehingga hasil pengujian ini sesuai dengan pernyataan bahwa semakin tinggi independensi auditor maka akan semakin baik pula kualitas audit yang dihasilkan. Penelitian ini sejalan dengan kajian empiris (Suyono 2012) (Suseno 2013) (Enofe et al. 2013)) Agusti and Pertiwi (2013),Ningsih and Yaniartha (2013), (Rahmina and Agoes 2014),Jamaluddin and Syarifuddin (2014),Sari, Wardoyo, and Laily (2015) Giovani and Rosyada (2019),yang menyatakan bahwa independensi auditor berpengaruh signifikan positif terhadap kualitas audit. Hal ini berarti semakin tinggi independensi seorang auditor, maka akan menghasilkan kualitas audit yang semakin baik. Sementara hasil studi ini tidak sejalan dengan kajian empiris (Tjun, Marpaung, and Setiawan 2012), (Efendy 2010) 
menemukan

independensi auditor

tidak

\section{KESIMPULAN DAN SARAN}

\section{Simpulan}

Kekuatan model secara keseluruhan dengan meihat koefisien determinasi, Q-Square Predictive Relevance dan Goodness of Fit (GoF) dinyatakan sangat baik.

Hipotesis 1, yang menyatakan profesionalisme auditor berpengaruh signifikan positif terhadap kualitas audit. Dalam pengujian , diperoleh bahwa profesionalisme auditor berpengaruh negatif dengan dengan p-value dibawah standar yang ditetapkan, itu berarti hipotesis $1\left(\mathrm{H}_{1}\right)$ tidak dapat diterima,

Hipotesis 2, yang menyatakan kompetensi auditor berpengaruh signifikan positif terhadap kualitas audit. Dalam pengujian, diperoleh bahwa kompetensi auditor berpengaruh positif dengan pvalue diatas standar yang ditetapkan, itu berarti hipotesis $2\left(\mathrm{H}_{2}\right)$ dapat diterima,

Hipotesis 3, yang menyatakan independensi

\section{DAFTAR PUSTAKA}

Armando, G. (2013). Pengaruh sistem pengendalian intern pemerintah dan pengawasan keuangan daerah terhadap nilai informasi laporan keuangan pemerintah (Studi Empiris pada SKPD di Kota Bukittinggi). Jurnal akuntansi, 1 (1).

Bimantara, Z. A., \& Handayani, S. R. (2017). Analisis Pengendalian Intern Dalam Sistem Akuntansi Penerimaan Kas Pelayanan Rawat Inap Dan Rawat Jalan Pasien Umum (Studi Pada Rumah Sakit Ibnu Sina Bojonegoro). Jurnal Administrasi Bisnis, 45(1), 203209.

Deddi, Iswahyudi, \& Maulidah. (2012). Akuntansi Pemerintahan. Jakarta: Salemba Empat.

Hamidah, R. T. (2014). Pengaruh Pelaksanaan Sistem Pengendalian Intern Pemerintah dan Sumber Daya Manusia Terhadap Pengamanan Aset Negara (Studi Empiris Pada Kementerian Perindustrian Wilayah Jawa Sumatera). Jurnal Akuntansi, 2(1).

Harahap, S., \& Syafri. (2004). Teori Akuntansi. Jakarta: PT Raja Grafindo Persada.

Ismani, 1., Istinigrum, A. A., Nugroho, M. A., \& Pustikaningsih, A. (2014). Implementasi Sistem Pengendalian Intern Pemerintah di Universitas Negeri Yogyakarta. Jurnal Economia, 10(1), 24-37.

KOMINFO. (2011, Mei 31). Retrieved from kominfo.go.id: https://kominfo.go.id/content/detail/457/sejarah/0/page auditor berpengaruh signifikan positif terhadap kualitas audit. Dalam pengujian, diperoleh bahwa independensi auditor berpengaruh positif dengan pvalue diatas standar yang ditetapkan, itu berarti hipotesis $3\left(\mathrm{H}_{3}\right)$ dapat diterima.

\section{Saran Saran}

Berdasarkan temuan penelitian dalam studi ini, ada beberapa saran yang perlu diajukan untuk para peneliti kedepan. Pertama, mengingat populasi penelitian sangat terbatas, maka kedepan diharapkan untuk bisa mengangkat jumlah responden yang lebih banyak.Kedua,perlu diangkat suatu penelitian model perilaku dengan menjaring pendapat responden menggunakan kuisioner campuran (tertutup dan semi tertutup). Ketiga, analisis penelitian dengan pendekatan $M M R$ (Mixed Method Research) sangat memungkinkan untuk menggali model penelitian kedepan sehingga lebih dapat menggambarkan perilaku responden yang lebih mendekati kenyataan.

Krismiaji. (2010). Sistem Informasi Akuntansi. Yogyakarta: AMP YKPN.

Latif, Z. (2017). Dinas Komunikasi dan Informatika Pemerintah Daerah Kabupaten Semarang. Retrieved from https://diskominfo.semarangkab.go.id: https://diskominfo.semarangkab.go.id/visi-misi/

Mokoginta, N., Lambey, L., \& Pontoh, W. (2017). Pengaruh Sistem Pengendalian Intern dan Sistem Akuntansi Keuangan Daerah terhadap Kualitas Laporan Keuangan Pemerintah. Jurnal Riset Akuntansi, 12 (2).

Mulyadi. (2001). Sistem Akuntansi. Jakarta: Salemba Empat.

Peraturan Bupati Nomor 8 Tahun 2019 Tentang Perubahan Atas Peraturan Bupati Semarang Nomor 52 Tahun 2016 Tentang Kedudukan, Susunan Organisasi, Tugas Dan Fungsi, Tata Kerja, Dan Perincian Tugas Perangkat Daerah Kabupaten Semarang. (2019).

Peraturan Pemerintah Nomor 60 Tahun 2008 Tentang Sistem Pengendalian Intern Pemerintah. (2008).

Purnomo, B. S. (2014). Pengaruh sistem pengendalian internal dan kekuatan koersif terhadap kualitas laporan keuangan Pemerintah Daerah. Jurnal Riset Akuntansi dan Keuangan, 2(1), 276-288.

Rama, \& Jones. (2016, Maret 17). Retrieved from http://fernandesocto.blogspot.co.id: http://fernandesocto.blogspot.co.id/2013/02/sistempenge ndalian-intern.html 
Ristanti, N. M., Sinarwati, N. K., \& Sujana, S. E. (2014). Pengaruh Sistem Pengendalian Intern, Pengelolaan Keuangan Daerah dan Komitmen Organisasi terhadap Penerapan Good Governance (Studi Kasus pada Satuan Kerja Perangkat Daerah Kabupaten Tabanan). JIMAT (Jurnal Ilmiah Mahasiswa Akuntansi) Undiksha, 2(1).
Sujarweni, \& Wiratna. (2015). Akuntansi Sektor Publik. Yogyakarta: Penerbit Pustaka Baru Press.

Suliyanto, S. E., \& MM, S. (2017). Metode Penelitian Kuantitatif. 